\title{
Studies on the Mechanisms of Food-Stimulated
}

\section{Gastric Acid Secretion in Normal Human Subjects}

\author{
Charles T. Ruchardson, John H. Walsh, Martha I. Hicks, and \\ JoHn S. FordTran \\ From the Medical Departments, The University of Texas Health Science \\ Center at Dallas, Dallas, Texas 75235 and the University of California at \\ Los Angeles, Los Angeles, California 90033
}

A в S T R A C T Liquid test meals were infused into the stomach and acid secretion was measured by intragastric titration at $\mathrm{pH} 5.0$. Acid secretion after 500 or $750-\mathrm{ml}$ sodium chloride meals was two to three times higher than basal secretion rates and was equivalent to $25-30 \%$ of the peak acid output in response to histamine. Since these meals did not cause a rise in serum gastrin concentration, it is assumed that they stimulate acid secretion by causing distention of the body and fundus of the stomach. Compared with this distention stimulus, glucose meals had no effect on acid secretion and fatinhibited acid secretion; however, both glucose and fat caused an increase in serum gastrin concentration. Amino acids caused a much greater increase in serum gastrin concentration and enhanced acid secretion above that noted with distention alone. In contrast, albumin did not enhance the serum gastrin concentration or stimulate acid secretion to a statistically significant extent.

There was a close correlation between the rise in serum gastrin concentration and rate of acid secretion after different test meals when average results for each test meal were plotted. However, there was a poor correlation between acid secretion and serum gastrin concentration when the responses of the individual subjects with a given test meal were compared.

Our interpretations are: (a) Distention is an important stimulant of the acid-secretory response to a meal, and this is not mediated by gastrin release. (b) Gastrin is one but probably not the only mediator of the chemical phase of acid secretion, i.e., acid secretion noted with amino acids that cannot be explained by distention. (c) Glucose and fat also release gastrin; however, with

Received for publication 12 March 1975 and in revised form 1 June 1976. glucose the rise in serum gastrin is too small and too transient to enhance acid secretion, and fat probably releases unmeasured inhibitors that overwhelm the effect of gastrin on acid secretion. (d) Albumin is not a stimulant of acid secretion.

\section{INTRODUCTION}

Until recently it was not possible to measure the rate of acid secretion when food was in the stomach, and almost all information on the response of the stomach to food has been obtained in laboratory animals with gastric pouches separated from the main stomach (Pavlov or Heidenhain pouches). Food is eaten or placed into the main stomach, and secretions from the pouch are collected and measured for acid output. Acid secreted by the pouch is assumed to be proportional to that secreted by the main stomach. It is recognized that this may not be a correct assumption, since the stomach but not the pouch is distended by the meal, and since the stomach but not the pouch mucosa is in direct content with food; however, this was the only way in which acid secretion after food could be estimated, and the method has been used extensively (1).

Recently, a method was developed for measuring gastric acid secretion in the presence of food (2). This involves the infusion of sodium bicarbonate into the stomach to maintain a constant intragastric $\mathrm{pH}$. The number of milliequivalents of bicarbonate required to prevent a fall in $\mathrm{pH}$ is equal to the rate of acid secretion. The method is simple and can be used in humans or laboratory animals with an intact stomach. The only unphysiologic aspect of this procedure is that gastric $\mathrm{pH}$ is maintained at a constant level rather than allowed to fall as acid is secreted. This does not appear to be a major disadvantage, since food-stimulated acid secre- 
tion can be measured at most $\mathrm{pH}$ levels within the physiologic range $(2,3)$. Furthermore, keeping $\mathrm{pH}$ constant controls important variables, such as the effect of hydrogen ion concentration on antral gastrin and intestinal enterogastrone release, that otherwise might influence the rate of acid secretion (4-6).

By this in vivo titration method, acid secretion in normal subjects after a meal consisting of steak, bread, and butter has been measured (2). Secretion increased immediately after eating and reached a maximal rate 90 min after the meal, at which time the secretion rate was approximately $80 \%$ of the stomach's maximal secretory response to histamine. By $4 \mathrm{~h}$ secretion was diminished, but was still about three times higher than basal secretion rate. Since the food stimulus was a mixed meal containing cooked protein, carbohydrate, and fat, it is not known to what extent the secretory response was mediated or inhibited by these separate dietary components. Since the meal was appetizing and was eaten in a normal fashion, cephalic influences may have mediated some of the secretory response.

In the present series of experiments we have studied the effects of sodium chloride, glucose, fat, amino acids, and albumin on gastric acid secretion and on serum gastrin concentration. The meals were injected into the stomach via a nasogastric tube so that cephalic influences were largely bypassed. From the results of these experiments we hoped to elucidate the role of gastric distention and of specific dietary components on the secretion of acid by the stomach and on the concentration of gastrin in serum.

\section{METHODS}

Subjects. 19 normal subjects were studied. Their average age was $31 \pm 2$ (range 21-46). The study was approved by a Human Research Review Committee, and informed consent was obtained from each subject.
Basal and peak histamine response. Basal acid secretion and the peak secretion rate after $0.04 \mathrm{mg} / \mathrm{kg}$ histamine acid phosphate were measured by standard aspiration methods (7). Hydrogen ion concentration was measured by the method of Moore and Scarlata (8).

Test meals. The compositions of the test meals for three different experiments (A, B, and $\mathrm{C}$ ) are shown in Table $\mathrm{I}$. The $\mathrm{pH}$ of each meal was adjusted to 5.0 by addition of sodium bicarbonate or hydrochloric acid. Within a given experiment, the osmolality of the different meals was constant. The meals were infused over a 5 -min period into the stomach through a Levin tube. Meals were given in random order on different tests days after a 10 -h fast.

Food-stimulated acid secretion. Acid secretory rate was measured for $2 \mathrm{~h}$ after the test meals by continuous intragastric titration (2). Meal samples were obtained every 2 min through a Levin tube, the $\mathrm{pH}$ was measured, and the samples were returned to the stomach. $0.3 \mathrm{~N}$ sodium bicarbonate was infused through a small polyvinyl tube at a rate required to maintain $\mathrm{pH}$ at 5.0. The number of milliequivalents of bicarbonate required to prevent a fall of gastric $\mathrm{pH}$ below 5.0 is equal to the number of milliequivalents of acid secreted.

Serum gastrin. Venous blood was collected through an indwelling catheter (Medicut i.v. cannula, A. S. Aloe Co., St. Louis, Mo.), kept open by a slow saline infusion. Blood samples were obtained immediately before the infusion of the meal and at $30,60,90$, and $120 \mathrm{~min}$ after the meal. In some experiments blood was also obtained at 10 and $20 \mathrm{~min}$ after the test meal. Blood was allowed to clot, and serum was obtained by centrifugation and stored at $-20^{\circ} \mathrm{C}$ until assayed.

Serum gastrin concentrations were measured by radioimmunoassay. All samples were tested in duplicate. In most experiments, antibody 1296, a rabbit antigastrin prepared by immunization with gastrin conjugated to bovine serum albumin, was used at a final dilution of $1: 300,000$ (9). With this antiserum, human heptadecapeptide gastrins and human big gastrins are measured on a nearly equimolar basis, big gastrins being approximately two-thirds as potent as the heptadecapeptides. Cross-reactivity with porcine cholecystokinin $(\mathrm{CCK})^{1}$ is less than $5 \%(10)$. In some ex-

${ }^{1}$ Abbreviations used in this paper: CCK, cholecystokinin; IGR, integrated gastrin response; PEG, polyethylene glycol.

TABLE I

Composition of Test Meals

Exp. A : Volume 500 or $750 \mathrm{ml}$, osmolality $220 \mathrm{mosmol} / \mathrm{kg}$

$\mathrm{NaCl} 0.643 \%$

Glucose, $14 \mathrm{~g}$; cornstarch, $120 \mathrm{~g}^{*}$

Casein hydrolysate, $12.8 \mathrm{~g} \ddagger$
Exp. B: Volume $500 \mathrm{ml}$.

osmolality $220 \mathrm{mosmol} / \mathrm{kg}$

Glucose, $14 \mathrm{~g}$; cornstarch, $120 \mathrm{~g}$

Glucose, $14 \mathrm{~g}$; cornstarch, $120 \mathrm{~g}$; Lipomul, $40 \mathrm{~g} \&$
Exp. C: Volume $500 \mathrm{ml}$, osmolality $480 \mathrm{mosmol} / \mathrm{kg}$

Carbohydrate and fat meal: controlyte, $50 \mathrm{~g} \|$; Lipomul, $15 \mathrm{~g}$; glucose qs osmolality $480 \mathrm{mosmol} / \mathrm{kg}$

Plus additional components : Casein hydrolysate, $1 \mathrm{~g}$

Casein hydrolysate, $20 \mathrm{~g}$

Albumin, $20 \mathrm{~g}$ I

* Cornstarch, Best Foods, Englewood Cliffs, N. J.

¥ Casein hydrolysate, Stuart Pharmaceuticals, Div. of ICI United States Inc., Wilmington, Del.

\$ Lipomul (corn oil), The Upjohn Company, Kalamazoo, Mich.

|| Controlyte, The Doyle Pharmaceutical Co., Minneapolis, Minn. Contains $36 \mathrm{~g}$ carbohydrate and $12 \mathrm{~g}$ fat/50 g Controlyte.

I Bovine albumin fraction, General Biochemicals, Div. North American Mogul Products Corp., Chagrin Falls, Ohio. 
ANTIBODY 1611

1. 200,000 Dilution

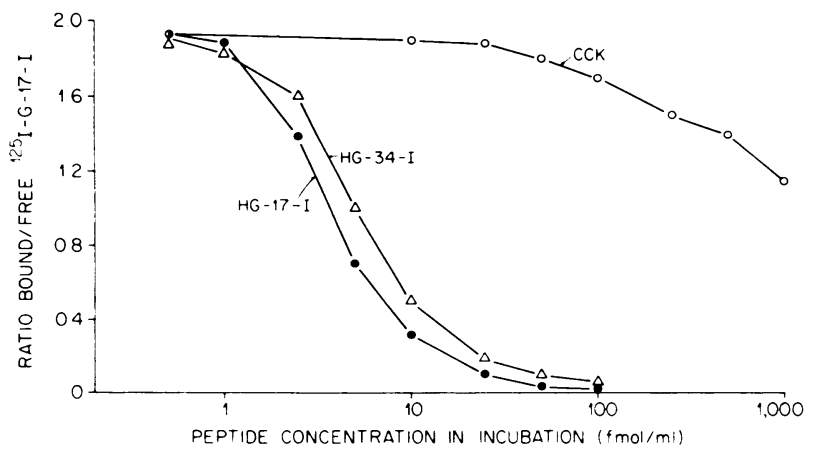

Figure 1 Competitive inhibition curves for pure natural human heptadecapeptide I (HG-17-I) and big gastrin (HG-34-I) and for pure natural porcine CCK with antibody 1611 at final dilution 1:200,000. Molar concentration of peptide in the final incubation mixture is shown on the abscissa and ratio of bound to free monoiodo ${ }^{125} \mathrm{I}-\mathrm{HG}-17-\mathrm{I}$ gastrin I on the ordinate.

periments serum samples were also assayed with antibody 1611 , which has a cross reactivity with porcine CCK of less than $0.3 \%$ (Fig. 1). Antibody 1611 was also prepared by immunization of a rabbit with gastrin conjugated to bovine serum albumin. It was used in a final dilution of $1: 200,000$. Results of the serum gastrin assay were expressed in picograms per milliliter with natural human heptadecapeptide gastrin I used as the standard.

Results of the serum gastrin response to the test meals are depicted on graphs that show mean values at each sampling interval after the meal, and in tables as the "integrated gastrin response" (IGR). IGR is calculated by the following formula :

$$
\begin{aligned}
\mathrm{IGR}= & \frac{\Delta G_{0}+\Delta G_{1}}{2} \times\left(t_{1}-t_{0}\right)+\frac{\Delta G_{1}+\Delta G_{2}}{2} \\
& \times\left(t_{2}-t_{1}\right)+\ldots+\frac{\Delta G_{\mathrm{n}-1}+\Delta G_{\mathrm{n}}}{2} \times\left(t_{\mathrm{n}}-t_{\mathrm{n}-1}\right)
\end{aligned}
$$

$\Delta G$ is serum gastrin concentration minus basal gastrin concentration; $t$ is time in minutes after the meal; and subscripts $0,1,2 \ldots$ n refer to successive sampling periods ( $0=$ basal sample so $\Delta G_{0}$ is always equal to zero).

Thus, unless the serum gastrin concentration falls to or below the basal value, the IGR always increases as the length of time after the meal increases. In this paper we report values for $0-30 \mathrm{~min}$ after the test meal if samples of serum were obtained at $0,10,20$, and $30 \mathrm{~min}$, and for 0-120 min when samples were obtained at $0,30,60,90$, and $120 \mathrm{~min}$ after the meal. The units are nanogramminutes per milliliter for 30 or $120 \mathrm{~min}$. The response of each subject was determined, and mean responses and statistical significance were then calculated.

Gastric emptying and gastric volume. In some subjects $12 \mathrm{~g}$ of polyethylene glycol (PEG) were added to the meals to evaluate gastric emptying and gastric volume. $2 \mathrm{~h}$ after infusion of the test meals, the stomach was emptied as completely as possible, and the volume $\left(V_{1}\right)$ and PEG concentration of the aspirated gastric contents were determined. The stomach was then rinsed with $400 \mathrm{ml}$ of $0.9 \%$ sodium chloride that did not contain PEG. The rinse was aspirated, the volume was measured, and an aliquot was analyzed for PEG. The gastric volume was calculated from $V_{1}$ plus the residual volume $\left(V_{2}\right) . V_{2}$ was calculated from the PEG concentration in $V_{1}$ and in the rinse solution by the following formula: $V_{2}=(\mathrm{Vol}$ of the rinse $\times$ [PEG] of rinse/[PEG] of $V_{1}$ ). Gastric emptying is expressed as the percent of the original $12 \mathrm{~g}$ PEG infused with the meal remaining in the stomach at $2 \mathrm{~h}$. PEG was analyzed by the method of Hyden (11).

\section{RESULTS}

Exp. A: effect of sodium chloride, glucose, and amino acids meals. As shown in Table II, acid secretion after the 500 and $750-\mathrm{ml} \mathrm{NaCl}$ meals averaged about $5 \mathrm{meq}$ during the first $30 \mathrm{~min}$ and about $20 \mathrm{meq}$ during the entire 2 -h test. These values were two to three times higher than basal secretion rate $(P<0.02$ by paired $t$ test) and were equivalent to $25-30 \%$ of the peak secretory response to histamine (Fig. 2). The pattern of acid secretion and serum gastrin concentration after the $\mathrm{NaCl}$ meals is shown in Fig. 3. Neither of the $\mathrm{NaCl}$ meals caused the serum gastrin concentration to rise above basal level (Table II and Fig. 3).
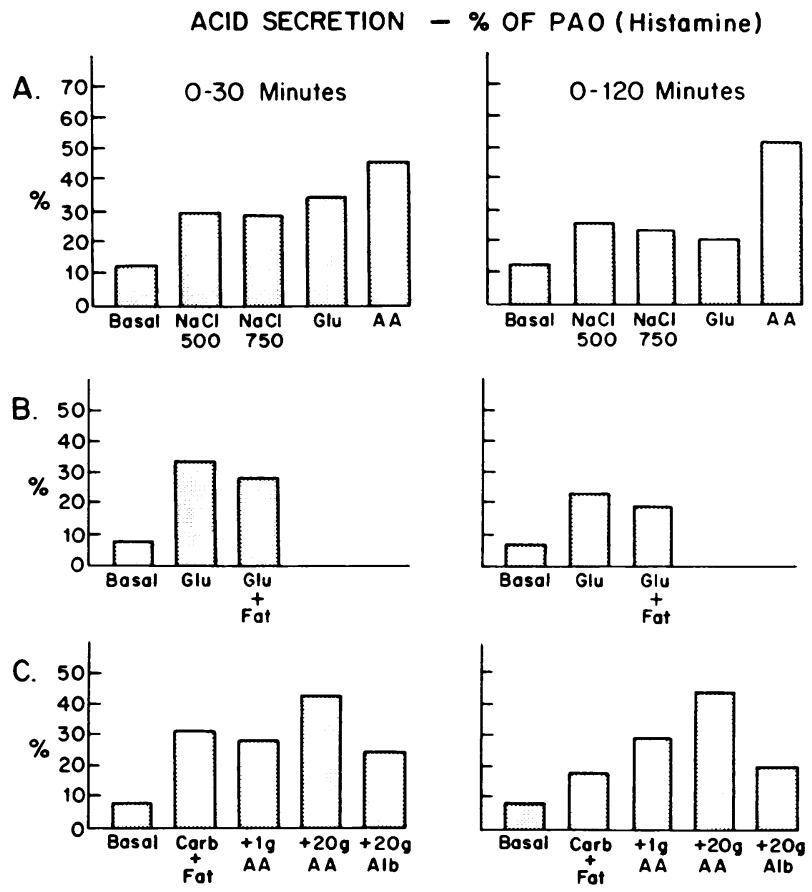

Figure 2 Acid secretion rate in the basal state (measured by aspiration) and after test meals (measured by in vivo titration to $\mathrm{pH} 5.0$ ), expressed as a percent of the peak acid output (PAO) in response to histamine $(0.04 \mathrm{mg} / \mathrm{kg}$ subcutaneously). All test meals had a volume of $500 \mathrm{ml}$ except as indicated. Glu, glucose; Carb, carbohydrate; AA, amino acids; Alb, albumin. The results shown in this figure are the average of the percent values of the individual subjects; therefore they do not agree exactly with similar calculations that could be made from mean data presented in the tables. 
TABLE II

Exp. A: Effect of NaCl, Glucose, and Amino Acids Meals on Acid Secretion and Serum Gastrin

\begin{tabular}{|c|c|c|c|c|}
\hline & \multicolumn{4}{|c|}{ Test meal } \\
\hline & $\mathrm{NaCl} 500 \mathrm{ml}$ & $\mathrm{NaCl} 750 \mathrm{ml}$ & Glucose $500 \mathrm{ml}$ & Amino acids $500 \mathrm{ml}$ \\
\hline \multicolumn{5}{|l|}{ Acid secretion } \\
\hline \multicolumn{5}{|l|}{$0-30 \mathrm{~min}$} \\
\hline Basal, meq & $2.3 \pm 0.5$ & $2.3 \pm 0.5$ & $2.3 \pm 0.5$ & $2.0 \pm 0.6$ \\
\hline Peak acid output, meq & $17.5 \pm 2.9$ & $17.5 \pm 2.9$ & $17.5 \pm 2.9$ & $17.2 \pm 3.6$ \\
\hline Test meal, meq & $5.5 \pm 1.5$ & $4.8 \pm 1.0$ & $5.6 \pm 0.7$ & $7.5 \pm 1.5$ \\
\hline \multicolumn{5}{|l|}{$0-120 \mathrm{~min}$} \\
\hline Basal, meq & $9.1 \pm 2.2$ & $9.1 \pm 2.2$ & $9.1 \pm 2.2$ & $7.8 \pm 2.4$ \\
\hline Peak acid output, meq & $70.0 \pm 11.5$ & $70.0 \pm 11.5$ & $70.0 \pm 11.5$ & $68.8 \pm 14.6$ \\
\hline Test meal, meq & $20.7 \pm 6.7$ & $18.3 \pm 5.5$ & $14.7 \pm 3.0$ & $34.7 \pm 7.7$ \\
\hline \multicolumn{5}{|l|}{ Serum gastrin* } \\
\hline \multicolumn{5}{|l|}{$0-30 \mathrm{~min}$} \\
\hline Basal, $p g / m l$ & $52 \pm 6$ & $49 \pm 3$ & $48 \pm 5$ & $64 \pm 14$ \\
\hline $\begin{array}{l}\text { Test meal IGR, } \ddagger \mathrm{ng} \cdot \min / \mathrm{ml} \\
0-120 \mathrm{~min}\end{array}$ & $0.01 \pm 0.1$ & $-0.12 \pm 0.1$ & $0.42 \pm 0.1 \|$ & $0.66 \pm 0.2 \S$ \\
\hline Basal, pg/ml & $52 \pm 6$ & $49 \pm 3$ & $48 \pm 5$ & $64 \pm 14$ \\
\hline Test meal IGR, $\ddagger n g \cdot \min / m l$ & $-0.26 \pm 0.5$ & $-0.65 \pm 0.3$ & $1.12 \pm 0.3$ & $2.47 \pm 0.9 \|$ \\
\hline
\end{tabular}

Ten subjects were studied with the $\mathrm{NaCl}$ and glucose meals and eight of these were studied with the amino acids meal. Acid secretion rate after each test meal was significantly higher $(P<0.02)$ than basal secretion rate. The average gastrin concentration after $500-750 \mathrm{ml} \mathrm{NaCl}$ was not significantly different from basal gastrin concentration. With glucose and amino acids the average gastrin concentration after the meals was higher than the basal gastrin concentration $(P<0.05)$.

* Mean \pm SE.

$\ddagger$ Integrated gastrin response.

$\S P<0.05 ; \| P<0.03$ when compared with the $500-\mathrm{ml} \mathrm{NaCl}$ meal by paired $t$ test.

The 500-ml glucose meal caused an acid-secretory response not significantly different from that of the $\mathrm{NaCl}$ meals (Table II, Figs. 2 and 3). However, glucose

ACID SECRETION

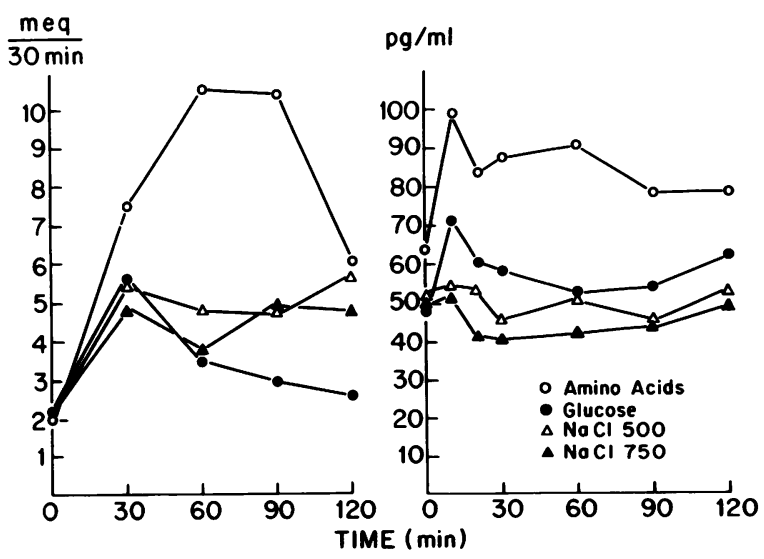

Figure 3 Exp. A: patterns of gastric acid secretion and serum gastrin response after test meals of $\mathrm{NaCl}$, glucose and amino acids. Test meal volume was $500 \mathrm{ml}$ except as indicated; the osmolality of all meals was $220 \mathrm{mosmol} / \mathrm{kg}$. Basal secretion and fasting serum gastrin concentration are indicated. Average results are shown in 10 normal subjects for $\mathrm{NaCl}$ and glucose and in 8 of these 10 subjects for the amino acids meals. caused a small but definite serum gastrin response during the first $30 \mathrm{~min}$ after the meal (Table II, Fig. 3).

The $500-\mathrm{ml}$ amino acids meal elicited a greater acidsecretory response than the other meals (Table II and Figs. 2 and 3). Over the 2 -h period, this response was about $50 \%$ as great as the peak secretory response to histamine (Fig. 2). The amino acids meal also caused a

TABLE III

Gastric Emptying and Gastric Volume 2 h after Test Meals

\begin{tabular}{|c|c|c|}
\hline & $\begin{array}{c}\text { PEG } \\
\text { remaining* }\end{array}$ & $\begin{array}{l}\text { Volume of } \\
\text { gastric } \\
\text { contents* }\end{array}$ \\
\hline & $\%$ & $m l$ \\
\hline \multicolumn{3}{|l|}{ Exp. A } \\
\hline $\mathrm{NaCl} 500 \mathrm{ml}$ & $\mathbf{0}$ & $46 \pm 7$ \\
\hline $\mathrm{NaCl} 750 \mathrm{ml}$ & $\mathbf{0}$ & $40 \pm 8$ \\
\hline Glucose $500 \mathrm{ml}$ & $16 \pm 4 \pi$ & $208 \pm 22 \pi$ \\
\hline Amino acids $500 \mathrm{ml}$ & $2 \pm 1$ & $67 \pm 24$ \\
\hline \multicolumn{3}{|l|}{ Exp. B } \\
\hline Glucose $500 \mathrm{ml}$ & $19 \pm 5$ & $209 \pm 30$ \\
\hline Glucose + Fat $500 \mathrm{ml}$ & $29 \pm 48$ & $273 \pm 278$ \\
\hline
\end{tabular}

* Mean \pm SE.

$\S P<0.05 ; \| P<0.03 ;$ I $P<0.01$ when compared to the first meal in a given experiment. 
TABLE IV

Exp. B: Effect of Glucose and Glucose plus $40 \mathrm{~g}$ of Corn Oil on Acid Secretion and Serum Gastrin

\begin{tabular}{|c|c|c|c|c|}
\hline & \multicolumn{2}{|c|}{$0-30 \min (n=6)$} & \multicolumn{2}{|c|}{$0-120 \min (n=20)$} \\
\hline & Glucose & Glucose + fat & Glucose & Glucose + fat \\
\hline \multicolumn{5}{|l|}{ Acid secretion, $m e q^{*}$} \\
\hline Basal & $1.5 \pm 0.7$ & $1.5 \pm 0.7$ & $5.0 \pm 1.4$ & $5.0 \pm 1.4$ \\
\hline Peak acid output & $18.2 \pm 3.0$ & $18.2 \pm 3.0$ & $70.0 \pm 6.3$ & $70.0 \pm 6.3$ \\
\hline Test meal & $6.0 \pm 1.0$ & $4.2 \pm 0.6$ & $15.6 \pm 1.8$ & $12.0 \pm 1.7 \S$ \\
\hline \multicolumn{5}{|l|}{ Serum gastrin* } \\
\hline Basal, $p g / m l$ & $54 \pm 6$ & $62 \pm 6$ & $57 \pm 10$ & $54 \pm 6$ \\
\hline Test meal, IGR, $\ddagger n g \cdot \min / m l$ & $0.58 \pm 0.12$ & $0.46 \pm 0.10$ & $0.51 \pm 0.38$ & $2.18 \pm 0.64 \S$ \\
\hline \multicolumn{5}{|c|}{$\begin{array}{l}\text { Acid secretion rate after both test meals was significantly higher than basal secretion rate } \\
(P<0.05) \text {. In the } 0-30 \text {-min studies, the average of the } 10,20 \text {, and } 30 \text { min gastrin concentrations } \\
\text { was significantly higher than basal gastrin concentration, with both test meals }(P<0.05) \text {. In the } \\
0-120 \text {-min studies, the average of the gastrin concentration of } 30,60,90 \text {, and } 120 \text { min was higher } \\
\text { than basal gastrin concentration for the glucose plus fat meal }(P<0.003) \text {, but not for the glucose } \\
\text { meal }(P>0.30) \text {. } \\
\text { * Mean } \pm \text { SE. } \\
\ddagger \text { Integrated gastrin response. } \\
\S P<0.05 \text { when compared with the glucose meal. }\end{array}$} \\
\hline
\end{tabular}

greater gastrin response than the other meals (Table II and Fig. 3).

As shown in Table III, the $\mathrm{NaCl}$ and amino acids meals were almost completely emptied from the stomach by the end of the 2-h experiment. By contrast, $16 \%$ of the PEG in the glucose meal was still in the stomach at the end of the $2 \mathrm{~h}$. Gastric volume at $2 \mathrm{~h}$ was also higher with glucose than with the other meals.

\section{ACID SECRETION}
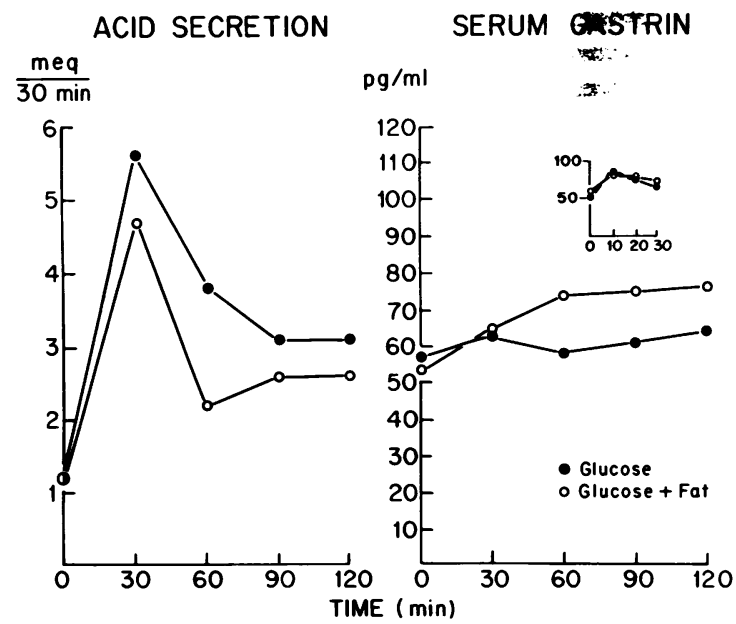

FIgURE 4 Exp. B : patterns of gastric acid secretion and serum gastrin response after a glucose meal with and without fat (40 g corn oil). Test meal volumes were $500 \mathrm{ml}$, osmolality $220 \mathrm{mosmol} / \mathrm{kg}$. Basal secretion and fasting serum gastrin concentration are indicated. Average results in 20 normal subjects are shown. The inset on the right panel shows mean results at 10,20 , and $30 \mathrm{~min}$ in 6 of the 20 subjects.
Exp. B : effect of a glucose meal with and without fat. As shown in Table IV, the addition of fat to a glucose meal inhibited the acid secretory response from 0 to 120 min from 15.6 to 12.0 meq $(P<0.05)$, but increased the $0-120 \mathrm{~min}$ integrated gastrin response from 0.51 to 2.18 ng-min $/ \mathrm{ml}(P<0.05)$. On the other hand, during the first $30 \mathrm{~min}$ after the meal, the response to the glucoseplus-fat meal was essentially the same as the response to the glucose meal without fat (Table IV and Fig. 4).

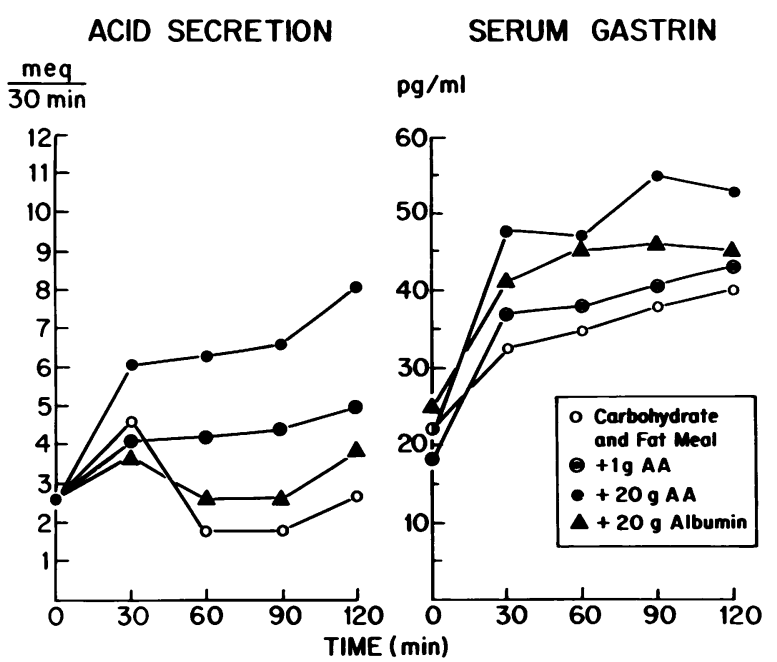

FIGURE 5 Exp. C: pattern of acid secretion and serum gastrin response after meals containing carbohydrate and fat plus various amounts of amino acids (AA) or albumin. Test meal volume was $500 \mathrm{ml}$, osmolality was $480 \mathrm{mosmol} /$ kg. Basal acid secretion and fasting serum gastrin concentration are indicated. Mean results in eight normal subjects are shown. 
TABLE V

Exp. B: Effect of Glucose and Glucose plus $40 \mathrm{~g}$ Corn Oil on Acid Secretion and Serum Gastrin Measured with Gastrin Antibody 1611 (Low Cross-Reactivity with $C C K$ ) in Six Normal Subjects

\begin{tabular}{lccccc}
\hline & \multicolumn{2}{c}{$0-30 \mathrm{~min}$} & & \multicolumn{2}{c}{$0-120 \mathrm{~min}$} \\
\cline { 2 - 3 } \cline { 5 - 6 } \cline { 5 - 6 } & Glucose & Glucose + fat & & Glucose & Glucose + fat \\
\hline Acid secretion, meq $^{*}$ & & & & \\
$\quad$ Basal & $1.5 \pm 0.7$ & $1.5 \pm 0.7$ & & $6.0 \pm 2.9$ & $6.0 \pm 2.9$ \\
Peak acid output & $18.2 \pm 3.0$ & $18.2 \pm 3.0$ & & $72.7 \pm 12.1$ & $72.7 \pm 12.1$ \\
Test meal & $6.0 \pm 1.0$ & $4.2 \pm 0.6$ & & $15.7 \pm 3.6$ & $13.1 \pm 2.1$ \\
Serum gastrin* & & & & \\
$\quad$ Basal, $p g / m l$ & & & & \\
Test meal, IGR $\ddagger$ & $0.18 \pm 0.10$ & $0.28 \pm 0.05$ & & $0.33 \pm 0.42$ & $1.93 \pm 0.31 \|$ \\
\hline
\end{tabular}

* Mean \pm SE.

$\ddagger$ Integrated gastrin response.

$\S P<0.05 ; \| P<0.03$ when compared with the glucose meal. Other differences were not statistically significant $(P>0.05)$.

In six of these subjects the serum gastrin response was measured with a gastrin antibody (1611) that has less than $0.3 \%$ reactivity with $\mathrm{CCK}$. Even with this antibody, fat enhanced the $0-120$-min gastrin response (Table V).

As shown in Table III, fat delayed gastric emptying of PEG and increased the volume of the gastric contents at the end of the 2-h experiment.

Exp. C: effect of amino acids and albumin. As shown in Table VI, 1 and $20 \mathrm{~g}$ of amino acids increased acid secretion above that with the carbohydrate and fat meal; $20 \mathrm{~g}$ of amino acids caused an acid-secretory response equal to $42 \%$ of the peak secretory response to hista- mine (Fig. 2). On the other hand, $20 \mathrm{~g}$ of albumin did not stimulate a significant increase in acid secretion.

Only the $20-\mathrm{g}$ amino acids meal elicited a statistically significantly higher gastrin response than the carbohydrate and fat meal (Table VI). The pattern of acid secretion and serum gastrin concentration after the meals is shown in Fig. 5.

Correlation of meal-stimulated acid secretion and integrated gastrin response. Fig. 6 shows the relationship between integrated gastrin response and meal-stimulated acid secretion (Exp. C). Data depicted in this figure represent the mean of the results in eight subjects studied in the basal state and after the four test

TABLE VI

Exp. C: Effect of 500-ml Test Meals on Acid Secretion and Serum Gastrin Concentration in Eight Normal Subjects

\begin{tabular}{|c|c|c|c|c|}
\hline & Carb and fat & $\begin{array}{c}\text { Carb and fat } \\
+1 \mathrm{~g} \mathrm{AA}\end{array}$ & $\begin{array}{l}\text { Carb and fat } \\
+20 \mathrm{~g} \mathrm{AA}\end{array}$ & $\begin{array}{c}\text { Carb and fat } \\
+20 \mathrm{~g} \mathrm{Alb}\end{array}$ \\
\hline \multicolumn{5}{|l|}{ Acid secretion, $m e q^{*}$} \\
\hline \multicolumn{5}{|l|}{$0-120 \mathrm{~min}$} \\
\hline Basal & $5.4 \pm 2.3$ & $5.4 \pm 2.3$ & $5.4 \pm 2.3$ & $5.4 \pm 2.3$ \\
\hline Peak acid output & $63.5 \pm 9.8$ & $63.5 \pm 9.8$ & $63.5 \pm 9.8$ & $63.5 \pm 9.8$ \\
\hline Test meal & $11.0 \pm 2.4$ & $17.7 \pm 3.3 \S$ & $27.1 \pm 5.8 \|$ & $12.8 \pm 3.8$ \\
\hline \multicolumn{5}{|l|}{ Serum gastrin* } \\
\hline \multicolumn{5}{|l|}{$0-120 \mathrm{~min}$} \\
\hline Basal, $p g / m l$ & $22 \pm 3$ & $21 \pm 3$ & $22 \pm 4$ & $25 \pm 3$ \\
\hline Test meal IGR, $\ddagger n g \cdot \min / m l$ & $1.42 \pm 0.33$ & $1.85 \pm 0.50$ & $2.95 \pm 0.48 \pi$ & $2.05 \pm 0.40$ \\
\hline
\end{tabular}

$*$ Mean \pm SE

$\ddagger$ Integrated gastrin response over the 120 -min test period.

$\S P<0.05 ; \| P<0.03 ;$ I $P<0.01$ when compared with the carbohydrate and fat test meal. In addition, the following paired $t$ test comparisons were made. Acid secretion: $20 \mathrm{~g}$ amino acids $>1 \mathrm{~g}$ amino acids, $P<0.05 ; 20 \mathrm{~g}$ amino acids $>20 \mathrm{~g}$ albumin $P<0.005$. Gastrin: $20 \mathrm{~g}$ amino acids $>1 \mathrm{~g}$ amino acids, $P<0.06 ; 20 \mathrm{~g}$ amino acids $>20 \mathrm{~g}$ albumin, $P<0.09$. Carb, carbohydrate; AA, amino acids; Alb, albumin. 
TABLE VII

Correlation Coefficients for Acid-Secretory Response and Integrated Gastrin Response with the Various Test Meals

\begin{tabular}{|c|c|c|c|c|c|c|}
\hline & \multicolumn{3}{|c|}{$0-30 \min$} & \multicolumn{3}{|c|}{$0-120 \min$} \\
\hline & $n$ & $r$ & $P$ & $n$ & $r$ & $P$ \\
\hline \multicolumn{7}{|l|}{ Exp. A } \\
\hline $\mathrm{NaCl}(500 \mathrm{ml})$ & 10 & +0.09 & $>0.1$ & 10 & +0.32 & $>0.1$ \\
\hline $\mathrm{NaCl}(750 \mathrm{ml})$ & 10 & -0.06 & $>0.1$ & 10 & +0.33 & $>0.1$ \\
\hline Glucose & 10 & +0.74 & $<0.05$ & 10 & -0.27 & $>0.1$ \\
\hline Amino acids & 8 & +0.23 & $>0.1$ & 8 & +0.14 & $>0.1$ \\
\hline \multicolumn{7}{|l|}{ Exp. B } \\
\hline Glucose & 6 & +0.36 & $>0.1$ & 20 & -0.02 & $>0.1$ \\
\hline Glucose + fat & 6 & +0.36 & $>0.1$ & 20 & +0.03 & $>0.1$ \\
\hline \multicolumn{7}{|l|}{ Exp. C } \\
\hline Carbohydrate and fat & & & & 8 & -0.49 & $>0.1$ \\
\hline$+1 \mathrm{~g}$ amino acids & & & & 8 & +0.31 & $>0.1$ \\
\hline$+20 \mathrm{~g}$ amino acids & & & & 8 & +0.44 & $>0.1$ \\
\hline$+20 \mathrm{~g}$ albumin & & & & 8 & -0.20 & $>0.1$ \\
\hline Cooked steak* & & & & 8 & +0.52 & $>0.1$ \\
\hline
\end{tabular}

$P$ values are from Documenta Geigy Scientific Tables, sixth edition, Konrad Diem, editor, Geigy Pharmaceuticals, Ardsley, N. Y., page 61. The $P$ values indicate the likelihood that the correlation is a chance phenomenon.

* Volume, $600 \mathrm{ml}$; osmolality, $135 \mathrm{mosmol} / \mathrm{kg}$.

meals listed in Table VI. There was a good correlation between the mean integrated gastrin response and the mean rate of acid secretion $(r=0.97)$.

Table VII gives the correlation coefficients for integrated gastrin response versus acid-secretory response among the individual subjects for all the test meals used in Exps. A, B, and C, and for a group of eight subjects given a homogenized cooked steak meal (volume 600 $\mathrm{ml}$; osmolality $135 \mathrm{mosmol} / \mathrm{kg}$; protein content, $37 \mathrm{~g}$, estimated from standard dietary tables). To normalize the results in individual subjects to a constant functional parietal cell mass (3), the acid-secretory response was calculated by subtracting basal acid secretion rate from the secretion rate after the meal and dividing this value by the peak acid secretion rate after histamine ( 0.04

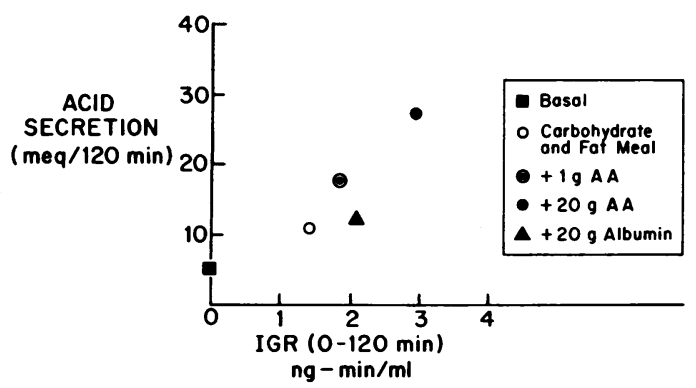

FIGURE 6 Correlation of integrated gastrin response (IGR) and acid secretion in the basal state and after various test meals $(r=0.97)$. Average results in eight normal subjects are shown. AA, amino acids. $\mathrm{mg} / \mathrm{kg}$ subcutaneously). Only one of the correlations was statistically significant (glucose, Exp. A, 0-30 min). This poor correlation was also present when peak gastrin concentration was compared with acid-secretory response. Fig. 7 shows the data after $12.8 \mathrm{~g}$ amino acids (Exp. A), which illustrates the poor correlation between gastrin response and acid secretion in these normal subjects.

Thus, test meals that elicit a high mean gastrin response by virtue of their amino acids or cooked protein

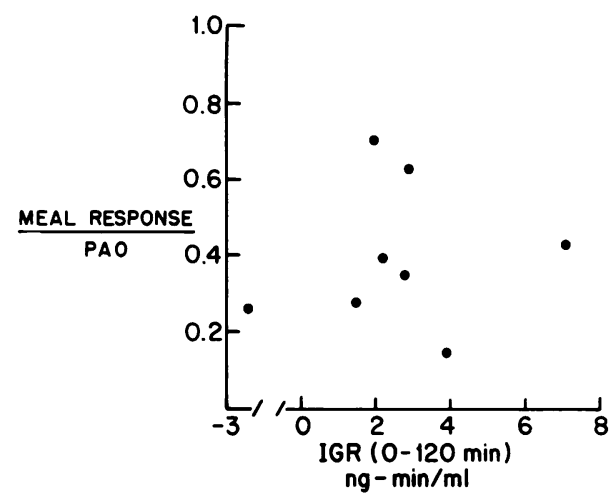

FIGURE 7 Lack of correlation of integrated gastrin response (IGR) and acid secretory response to amino acids test meal (Exp. A). The secretory response is the increase in acid secretion (above basal) after the meal, expressed as a fraction of the peak acid output (histamine). The correlation coefficient for this comparison was +0.14 with a $P$ value of $>0.1$. 
and polypeptide content elicit increased mean secretion rates of acid; however, with any given test meal there is poor correlation between gastrin response and acid secretion when values for the individual subjects are plotted.

\section{DISCUSSION}

Based on previous research in dogs with Pavlov and Heidenhain pouches, the major potential mechanisms for food stimulation of acid secretion via the "gastric phase" are thought to be: gastric distention and chemical reactions. Gastric distention can stimulate acid secretion in three ways. First, antral distention releases gastrin $(1,4)$. Second, antral distention stimulates acid secretion by a neural reflex (pyloro-oxyntic reflex) that is independent of a rise in serum gastrin (12). And third, distention of the body and fundus of the stomach stimulates acid secretion by local and vagovagal reflexes (1). Insofar as chemical reactions are concerned, the only known stimuli are amino acids and polypeptides. These interact with antral gastrin cells to cause gastrin release $(4,13)$ and directly with oxyntic cells in the body and fundus regions of the stomach to stimulate acid secretion (14). Carbohydrates and fats are not known to have similar chemical effects.

Although these mechanisms cause acid secretion and gastrin release in dogs under certain specific experimental conditions, it is not known to what extent they contribute to acid secretion and gastrin release after the ingestion of food in either humans or experimental animals. In the present studies we infused various artificial test meals into the stomach of normal human subjects and measured acid secretion and serum gastrin concentration. We will discuss our findings in terms of the effect of gastric distention, glucose, fat, amino acids and protein, and correlation of serum gastrin and acidsecretory responses.

Gastric distention. Acid secretion after 500- and 750$\mathrm{ml} \mathrm{NaCl}$ meals was two to three times higher than the basal secretion rate and was equivalent to $25-30 \%$ of the peak secretory response to histamine. However, these meals did not cause a rise in serum gastrin concentration. We conclude that $500-$ and $750-\mathrm{ml}$ liquid test meals do not produce sufficient antral distention to cause the release of gastrin, at least not enough to cause a measurable rise in gastrin concentration of peripheral venous blood. Since animal studies suggest that antral distention sufficient to activate a pyloro-oxyntic reflex would also cause an elevation of serum gastrin concentration when antral $\mathrm{pH}$ is 5.0 (12), it seems unlikely that such a reflex contributed to the observed acid-secretory response. On the assumption that $\mathrm{NaCl}$ does not stimulate the parietal cells by a direct chemical reaction, we conclude that gastric distention stimulates acid secretion and that this is probably mediated by local reflexes in the body and fundus of the stomach.

Glucose. The $500-\mathrm{ml}$ glucose test meal elevated serum gastrin concentration, but only during the first $30 \mathrm{~min}$ Although the glucose meal was emptied slower than the $\mathrm{NaCl}$ meals, it is difficult to attribute a rise in gastrin during the first $30 \mathrm{~min}$ after a $500-\mathrm{ml}$ glucose meal to antral distention, since even $750-\mathrm{ml} \mathrm{NaCl}$ meals do not elevate serum gastrin concentration. Therefore, we conclude that glucose either reacts chemically with antral gastrin cells to stimulate gastrin release or that glucose releases another hormone, which in turn releases gastrin. Whatever the mechanism, glucose caused only a relatively small and transient increase in serum gastrin concentration, not enough to increase acid secretion above that seen with the $\mathrm{NaCl}$ meals.

Fat. Addition of fat to the test meal increased the serum gastrin concentration. We considered the possibility that this might have resulted from antral distention secondary to delayed gastric emptying, but this seems unlikely since $750-\mathrm{ml} \mathrm{NaCl}$ meals did not raise the serum gastrin concentration and since gastric volume was only $64 \mathrm{ml}$ higher with than without fat at the end of the $2 \mathrm{~h}$ experiment (Table III). Another possibility is that fat elevates the serum concentration of CCK and that this cross-reacts in the gastrin assay system. To evaluate this, we repeated the experiment using a gastrin antibody that has almost no cross-reactivity with CCK. Fat meals still elevated the serum gastrin concentration. We tentatively conclude that fat reacts chemically with gastrin-cells to cause gastrin release or that fat releases an intermediate hormone that then causes gastrin release. These findings with fat were unexpected; however, we are aware of no previous studies in humans or animals where the question has specifically been evaluated by studying the effects of carbohydrate meals with and without fat.

Although fat caused a rise in serum gastrin concentration, fat inhibited acid secretion by $25 \%$ (Table IV). Presumably fat releases hormonal inhibitors of acid secretion $(15,16)$ that overwhelm the stimulatory effect of the released gastrin.

Amino acids and protein. When compared with the $\mathrm{NaCl}$ and glucose meals, amino acids elevated acid secretion and serum gastrin concentration throughout the entire $2 \mathrm{~h}$ experiment. Albumin, on the other hand, did not elevate acid secretion or serum gastrin concentration to a statistically significant extent. This suggests that pure protein is a relatively poor stimulant. (Under our experimental conditions $[\mathrm{pH} \mathrm{5.0]}$ peptic digestion is inhibited and peptides and amino acids would not be liberated from albumin in the stomach lumen.) However, both in the present studies and in our previous studies, 
steak in somewhat larger quantities is a potent stimulant of acid secretion and gastrin release $(2,3)$.

Correlation of serum gastrin and acid-secretory responses. Test meals containing amino acids caused a higher acid secretion rate than meals of equal volume and osmolality that did not contain amino acids. For purposes of this discussion, this increment in acid secretion (above that noted with meals of equal volume and osmolality that did not contain amino acids) will be referred to as the chemical phase of acid secretion. Test meals containing amino acids also evoked a greater gastrin response than other meals, and the correlation between this rise in serum gastrin concentration and the rate of acid secretion was excellent when average results for each test meal were plotted (Fig. 6). However, this does not necessarily mean that gastrin is the only, or even the major, mediator, of the chemical phase of acid secretion, since amino acids might stimulate acid secretion in other ways. For example, they might stimulate the parietal cells directly (14), or they might cause the release of a nongastrin stimulant from the small intestine. The fact that the correlation between the rise in serum gastrin concentration and the acid secretory responses among individual subjects given the amino acids or cooked steak meal was poor (Table VII and Fig. 7) suggests that gastrin may not be the only mediator of the chemical phase of acid secretion.

\section{ACKNOWLEDGMENTS}

We wish to thank Kathy Cooper, Barbara Bailey, Vicki Jones, and Helen Wong for their expert technical assistance.

This study was supported by research grants 1-R01-16816 and 1-R01-17294 from the National Institute of Arthritis, Metabolism and Digestive Diseases.

\section{REFERENCES}

1. Grossman, M. I. 1967. Neural and hormonal stimulation of gastric secretion of acid. Handb. Physiol. Section 6: alimentary canal. 2: 835-863.

2. Fordtran, J. S., and J. H. Walsh. 1973. Gastric acid secretion rate and buffer content of the stomach after eating. Results in normal subjects and in patients with duodenal ulcer. J. Clin. Invest. 52: 645-657.

3. Walsh, J. H., C. T. Richardson, and J. S. Fordtran. 1975. $\mathrm{pH}$ dependence of acid secretion and gastrin release in normal and ulcer subjects. J. Clin. Invest. 55: 462-468.

4. Elwin, C. E., and B. Uvnäs. 1966. Distribution and local release of gastrin. In Gastrin. M. I. Grossman, editor. University of California Press, Los Angeles. 69-82.

5. Chey, W. Y., S. Hitanant, J. Hendricks, and S. H. Lorber. 1970. Effect of secretin and cholecystokinin on gastric emptying and gastric secretion in man. Gastroenterology. 58: 820-827.

6. Brooks, A. M., and M. I. Grossman. 1970. Effect of secretin and cholecystokinin on pentagastrin-stimulated gastric secretion in man. Gastroenterology. 59: 114-119.

7. Baron, J. H. 1963. Measurement and nomenclature of gastric acid. Gastroenterology. 45: 118-121.

8. Moore, E. W., and R. W. Scarlata. 1965. The determination of gastric acidity by the glass electrode. Gastroenterology. 49 : 178-188.

9. Walsh, J. H. 1974. Radioimmunoassay of gastrin. In Nuclear Medicine In Vitro, B. Rothfeld, editor. J. B. Lippincott Company, Philadelphia, $\mathrm{Pa}$. 231-248.

10. Dockray, G. J., and J. H. Walsh. 1975. Amino terminal gastrin fragment in serum of Zollinger-Ellison syndrome patients. Gastroenterology. 68: 222-230.

11. Hyden, S. 1955. A turbidometric method for the determination of higher polyethylene glycols in biological materials. Lantbruksirogsk. Ann. 22: 139-145.

12. Debas, H. T., S. J. Konturek, J. H. Walsh, and M. I. Grossman. 1974. Proof of a pyloro-oxyntic reflex for stimulation of acid secretion. Gastroenterology. 66: 526532.

13. Debas, H. T., J. H. Walsh, and M. I. Grossman. 1974. Release of antral gastrin by large polypeptides. Clin. Res. 22: 171-A. (Abstr.)

14. Debas, H. T., and M. I. Grossman. 1974. Chemicals bathing oxyntic gland area stimulate acid secretion. Gastroenterology. 66: 836. (Abstr.)

15. Windsor, C. W. O., R. Cockel, and M. J. R. Lee. 1969. Inhibition of gastric secretion in man by intestinal fat infusion. Gut. 10: 135-142.

16. Johnson, L. R., and M. I. Grossman. 1971. Intestinal hormones as inhibitors of gastric secretion. Gastroenterology. 60 : $120-144$. 